\title{
Relationship between the Subunit Structure of Insulin Receptor and Its Competence to Bind Insulin and Undergo Phosphorylation'
}

\author{
DENNIS T. PANG, ${ }^{2}$ SIDNEY D. LEWIS, BALDEV R. SHARMA, \\ AND JULES A. SHAFER ${ }^{3}$
}

Department of Biological Chemistry, University of Michigan, Ann Arbor, Michigan 48109

Received April 20, 1984, and in revised form July 3, 1984

Insulin receptor partially purified from human placenta by chromatography on immobilized wheat germ agglutinin was subjected to affinity cross linking to determine the relationship between the subunit structure of the multiple forms of the insulin receptor and their competence to bind insulin and undergo autophosphorylation. It was demonstrated that, whereas the $340-\mathrm{kDa}$ intact receptor undergoes autophosphorylation, the 290 - and $320-\mathrm{kDa}$ insulin binding forms of the receptor do not. Phosphorylation at tyrosyl residues in the intact receptor was verified using a new facile method for determination of phosphorylated amino acids. The competence of the phosphorylated $340-\mathrm{kDa}$ protein to bind insulin was demonstrated using a doubleprobe labeling protocol wherein receptor phosphorylated with $\left[\gamma^{-32} \mathrm{P}\right] \mathrm{ATP}$ was crosslinked with disuccinimidyl suberate (DSS) in the presence of $N^{\mathrm{eB} 29}$-biotinylinsulin. The observation that succinylavidin, by virtue of its interaction with biotinyl residues, decreased the electrophoretic mobility of receptor radiochemically labeled with ${ }^{32} \mathbf{P}$ indicated that the phosphorylated $340-\mathrm{kDa}$ protein was competent to bind insulin. This result is compelling evidence that the $340-\mathrm{kDa}$ phosphorylated species is insulin receptor itself, rather than a closely associated contaminant. Treatment of the receptor with the crosslinking agent DSS produced (after reduction and denaturation) $\alpha$-dimer, $\beta$-dimer, and a smaller amount of tetramer. This observation is consistent with a symmetrical, tetrameric, $\alpha_{2} \beta_{2}$ structure for insulin receptor from human placenta, and excludes previously proposed alternative structures containing one $\alpha$ and one $\beta$ chain. $\odot 1984$ Academic Press, Inc.

The structure and mode of action of insulin receptor have been discussed in recent reviews $(1,2)$. Structural studies of insulin receptor which had been labeled with affinity labels (3-5) or biosynthetic precursors (6-8) support the view that the receptor is a symmetrical tetrameric transmembrane glycoprotein, consisting of two insulin binding $\alpha$ subunits and two

\footnotetext{
${ }^{1}$ Financial support for this work was from National Institutes of Health Grant AM 27659.

${ }^{2}$ Part of this work is described in a Ph.D. dissertation to be submitted to the Graduate School of The University of Michigan.

"To whom correspondence should be addressed.
}

$\beta$ subunits. The $\beta$-subunits of the receptor have recently been discovered to undergo insulin-dependent phosphorylation $(9,10)$. In vitro studies indicate that the $\beta$ subunit of solubilized receptor is autophosphorylated specifically at tyrosyl residues (9, $11,12)$, and that this subunit also contains an ATP binding site $(13,14)$. Additionally, solubilized receptor has been shown to catalyze insulin-dependent phosphorylation of tyrosyl residues in exogenous substrates $(11,15,16)$. Interestingly, several viral oncogene products (17) and growth factor receptors (18) also catalyze phosphorylation of tyrosyl residues, suggesting that protein phosphorylation at tyrosyl 
residues may be involved in the initiation of cellular proliferation in addition to triggering the cellular response to insulin. Determination of the linkage (if any) between tyrosyl phosphorylation and the cellular response to insulin, however, is likely to require further characterization of the structure and interactions of the autophosphorylated insulin receptor.

In this work results of affinity crosslinking and double-probe labeling studies are presented which support the symmetrical $\alpha_{2} \beta_{2}$ structure proposed for the insulin receptor, and establish that only the intact form of the insulin receptor is competent to both bind insulin and undergo autophosphorylation.

\section{MATERIALS AND METHODS}

[ $\left.\gamma^{-}{ }^{32} P\right]$ ATP was obtained from ICN. Human antiinsulin receptor serum was generously provided by Dr. Kahn and Dr. White (of the Joslin Diabetes Center).

Phosphorylation of insulin receptor. WGA'-purified receptor $(10 \mu \mathrm{g})$, in $100 \mu \mathrm{l}$, was preincubated with $100 \mathrm{nM}$ insulin in $25 \mathrm{~mm}$ Hepes, pH 7.6, 0.05\% Triton $\mathrm{X}-100,5 \mathrm{mM} \mathrm{MnCl}_{2}$ for $1 \mathrm{~h}$ at room temperature, whereupon phosphorylation was initiated by addition of $10 \mu \mathrm{l} 0.55 \mathrm{mM}$ ATP, containing 5-20 $\mu \mathrm{Ci}[\gamma-$ ${ }^{32}$ P]ATP. After the desired time period, the reaction was quenched by addition of twofold concentrated Laemmli sample buffer containing $50 \mathrm{mM}$ DTT instead of $\beta$-mercaptoethanol, heated at $95^{\circ} \mathrm{C}$ for 3 min, and subjected to SDS-PAGE (19).

Crasslinking of phasphoryluted insulin recepter with insulin. WGA-purified receptor, $20 \mu \mathrm{g}$ in $200 \mu \mathrm{l}$, was incubated with $100 \mathrm{nM}$ insulin, with or without ${ }^{125} \mathrm{I}$ insulin, in $25 \mathrm{~mm}$ Hepes, pH 7.6, $0.1 \mathrm{M} \mathrm{NaCl}, 0.1 \%$ BSA, $0.04 \%$ Triton, $5 \mathrm{mM} \mathrm{MnCl}_{2}$ at room temperature for $1 \mathrm{~h}$. Phosphorylation was initiated by addition of $10 \mu \mathrm{l} 1 \mathrm{mM}$ ATP, with and without $5 \mu \mathrm{Ci}\left[\gamma^{-}\right.$ ${ }^{32}$ P]ATP, to samples without and with ${ }^{125}$ I-insulin, respectively. After $5 \mathrm{~min}$ at room temperature, the reaction mixture was cooled in an ice bath and the receptor was crosslinked by addition of $2 \mu \mathrm{l} 30 \mathrm{mM}$

\footnotetext{
Abbreviations used: DSS, disuccinimidyl suberate; $\mathrm{Me}_{2} \mathrm{SO}$, dimethyl sulfoxide; PTC, phenylthiocarbamyl; SDS, sodium dodecyl sulfate; SDS-PAGE, polyacrylamide gel electrophoresis done in the presence of SDS; TEA, triethylamine; WGA, wheat germ agglutinin; Hepes 4-(2-hydroxyethyl)-1-piperazineethane sulfonic acid; BSA, bovine serum albumin; DTT, dithiothreitol; TPCK, L-1- $p$-tosylamino-2-phenylethylchloromethyl ketone.
}

DSS in $\mathrm{Me}_{2} \mathrm{SO}$. After $45 \mathrm{~min}$, the reaction mixture was quenched by addition of an equal volume of a twofold concentrated nonreducing sample buffer, heated at $95^{\circ} \mathrm{C}$ for $3 \mathrm{~min}$, and subjected to SDSPAGE.

Crosslinking of phosphorylated insulin receptor with biotinylinsulin. This procedure was similar to the one above, but with some modifications. The receptor was incubated with 5-100 $\mathrm{nM} N^{\mathrm{Br} 9}$-biotinylinsulin at $4^{\circ} \mathrm{C}$ for $15 \mathrm{~h}$, and phosphorylated for $5 \mathrm{~min}$ at room temperature. The crosslinking reaction was quenched by addition of an equal volume of twofold concentrated nonreducing sample buffer, containing $1.25 \%$ SDS (instead of $2 \%$ ). Before being applied to the slab gel, $40 \mu$ l of sample was incubated with 10 $\mu \mathrm{l}$ of $5 \mathrm{mg} / \mathrm{ml}$ succinylavidin at room temperature for $1 \mathrm{~h}$.

Polyacrylamide gel electrophoresis. SDS-PAGE was performed as described by Laemmli (19). Samples were heated for $3 \mathrm{~min}$ at $95^{\circ} \mathrm{C}$ in sample buffer with or without 25 mM DTT. Usually, nonreduced samples were analyzed in $4.5 \%$ separation gels with acrylamide: $N, N^{\prime}$-methylenebisacrylamide in a ratio of 30:0.3. Reduced samples were analyzed in $7.5 \%$ separation gels with an acrylamide: $N, N^{\prime}$-methylenebisacrylamide ratio of $30: 0.8$. Normally, electrophoresis was performed at room temperature but, for samples treated with succinylavidin, it was at $4^{\circ} \mathrm{C}$. After electrophoresis, the gel was stained, destained, soaked with $\mathbf{3} \%$ glycerol for $10 \mathrm{~min}$, and finally air-dried in between two cellophane membranes (from Bio-Rad). The staining and destaining solutions were water: isopropanol:acetic acid (330:120:5), with and without $0.05 \%$ Coomassie blue, respectively. For autoradiography, Kodak X-Omat film was flashed before use (20), and a DuPont High-Speed Cronex X-ray screen was used for enhancement of detection. For following the time course of autophosphorylation of the receptor, the 95K radioactive band was excised from the dried gel using the autoradiogram to locate the band. After addition of $3 \mathrm{ml}$ of aqueous counting scintillant (from Amersham), the radioactivity in the gel slices was measured in a Packard liquid scintillation spectrometer. Background radioactivity was measured in a gel slice of equal area above the 95K band. For experiments which involved a second SDS-PAGE, the receptor bands were excised from the dried gel using the autoradiogram to locate the bands. The gel slices were further cut into smaller pieces and added into sample wells of the second slab gel. Finally, $50 \mu \mathrm{l}$ sample buffer, with or without $25 \mathrm{mM}$ DTT, was added. After $15 \mathrm{~min}$ of gel swelling, electrophoresis was started.

Determination of the identity of the phosphorylated aminoacyl residues. The $95-\mathrm{kDa}$ autophosphorylated species located after SDS-PAGE by autoradiography was cut out of the gel, and suspended with stirring in $2 \mathrm{ml} 50 \mathrm{~mm}$ ammonium bicarbonate ( $\mathrm{pH} 8.0$ ) 
containing $100 \mu \mathrm{g}$ TPCK-treated trypsin (Worthington). After stirring for $24 \mathrm{~h}$ at $37^{\circ} \mathrm{C}$, the supernatant solution was lyophilized. The resulting dried tryptic digest was transferred to a $6 \times 50-\mathrm{mm}$ test tube using the minimum amount of $\mathrm{H}_{2} \mathrm{O}$ to effect the transfer. Small-volume aliquots of unlabeled $O$ phosphoamino acid standards (50-100 nmol) and the internal standard $\alpha$-aminobutyric acid (50-100 nmol) were added. After taking the contents of the $6 \times 50$ $\mathrm{mm}$ tube to dryness under reduced pressure, the tube was put in a $40-\mathrm{ml}$ screw cap vial (Pierce No. 13075) containing 1-2 $\mathrm{ml}$ of double-distilled, constantboiling $\mathrm{HCl}$ containing $0.1 \%$ phenol. The vial was flushed with nitrogen, capped (Pierce No. 13219) securely, and kept at $110^{\circ} \mathrm{C}$ for $1.5 \mathrm{~h}$ to effect hydrolysis by the $\mathrm{HCl}$ vapors. Phenylthiocarbamyl (PTC) derivatives of amino acids were prepared and analyzed using a modification of the general procedure for PTC-amino acid analysis by Koop et al. (21).

After $1.5 \mathrm{~h}$ at $110^{\circ} \mathrm{C}$, the small acidic residue in the $6 \times 50-\mathrm{mm}$ tube was taken to dryness under reduced pressure. Evaporation under reduced pressure was repeated after the following additions: 10 $\mu 1 \mathrm{H}_{2} \mathrm{O}$ twice, $10 \mu \mathrm{l} 50 \mathrm{mM}$ EDTA, and $10 \mu \mathrm{l}$ TEA twice. The dried sample was mixed on a vortex mixer with $3 \mu 150 \%$ ethanol, and then mixed with $10 \mu \mathrm{l}$ of the PTC reaction mixture consisting of $90 \%$ ethanol:TEA:phenylisothiocyanate (7:2:1). The tube was covered and allowed to react for $10 \mathrm{~min}$ at room temperature. The reaction mixture was taken to dryness under reduced pressure. The residue was taken up in HPLC starting eluant $(14 \%$ B) and centrifuged, and the supernatant solution was subjected to analysis by HPLC with a Varian 5000 equipped with a Rheodyne injector using an Altex Ultrasphere ODS column $(5 \mu \mathrm{m}, 4.6 \times 250 \mathrm{~mm})$ at room temperature. The separation was achieved at constant flow rate $(1.0 \mathrm{ml} / \mathrm{min})$ with a two-eluant system, using the following elution program: Initial conditions, $14 \% \mathrm{~B}$; at $10 \mathrm{~min}$ step to $22 \% \mathrm{~B}$; at 13.5 min step to $26 \% \mathrm{~B}$; at $21.4 \mathrm{~min}$ step to $36 \% \mathrm{~B}$; at 27 min step to $100 \% \mathrm{~B}$. Eluant A was $0.07 \mathrm{M}$ phosphoric acid (Fischer, HPLC grade) adjusted to $\mathrm{pH} 6.8$ with TEA, and eluant $B$ was $100 \%$ acetonitrile (Fischer, HPLC grade). The detection of the PTC-amino acids was accomplished by monitoring absorbance at 254 $\mathrm{nm}$ using a Model $\mathbf{4 5 0}$ variable-wavelength detector from Waters Associates. ${ }^{82} \mathrm{P}$ activity was detected by mixing the $0.5-\mathrm{ml}$ fractions, collected during HPLC, with $3.0 \mathrm{ml}$ scintillation cocktail (ACS, Amersham), and counting the samples in a Packard liquid scintillation spectrometer.

The sources of the other materials and the protocols for the other methods used in this work have been described previously $(22,23)$.

\section{RESULTS AND DISCUSSION}

Figure 1 illustrates the insulin-mediated autophosphorylation that occurred when WGA-purified insulin receptor from human placenta was incubated with $[\gamma-$ ${ }^{32}$ P]ATP. The autoradiogram upon SDSPAGE of the reduced labeled receptor revealed specific labeling of the $95-\mathrm{kDa}$ species which corresponds to the mass of the $\beta$ subunit of the insulin receptor. Consistent with the view that the phosphorylated $95-\mathrm{kDa}$ species is an integral part of the insulin receptor, addition of antireceptor antibody after phosphorylation produced a precipitate which, upon

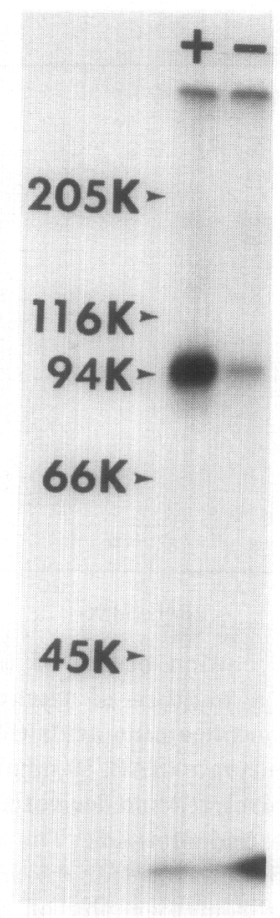

FIG. 1. Insulin-dependent phosphorylation of WGApurified receptor. WGA-purified receptor $(10 \mu \mathrm{g}$ in $100 \mu$ l) was preincubated with $(+)$ and without $(-)$ $100 \mathrm{nM}$ insulin at room temperature for $1 \mathrm{~h}$. [ $\gamma^{-}$ ${ }^{82}$ P]ATP was then added, and phosphorylation was allowed to proceed for $3.5 \mathrm{~min}$. The subsequent steps of SDS-PAGE (7.5\% acrylamide) and autoradiography were carried out as described under Materials and Methods. Shown is an autoradiogram of a dried gel. The positions of molecular weight markers are shown on the left (myosin, $205 \mathrm{kDa} ; \beta$-galactosidase, $116 \mathrm{kDa}$; phosphorylase $b, 94 \mathrm{kDa}$; bovine albumin, $66 \mathrm{kDa}$; ovalbumin, $45 \mathrm{kDa}$ ). 
reduction with DTT in the presence of SDS followed by SDS-PAGE and autoradiography, showed the $95-\mathrm{kDa}$ band, whereas similar treatment of the supernatant solution from the immunoprecipitate revealed only a trace of the $95-\mathrm{kDa}$ band. The phosphorylated amino acid in the $95-\mathrm{kDa}$ species was found to be primarily phosphotyrosine by subjecting the excised section of the gel containing the $95-\mathrm{kDa}$ band to digestion with trypsin followed by limited acid hydrolysis of the solubilized peptides. Phosphoamino acids were separated and quantified by HPLC on a $\mathrm{C}_{18}$ column after they had been converted to PTC derivatives by reaction with Edman's reagent (Fig. 2). These ob-

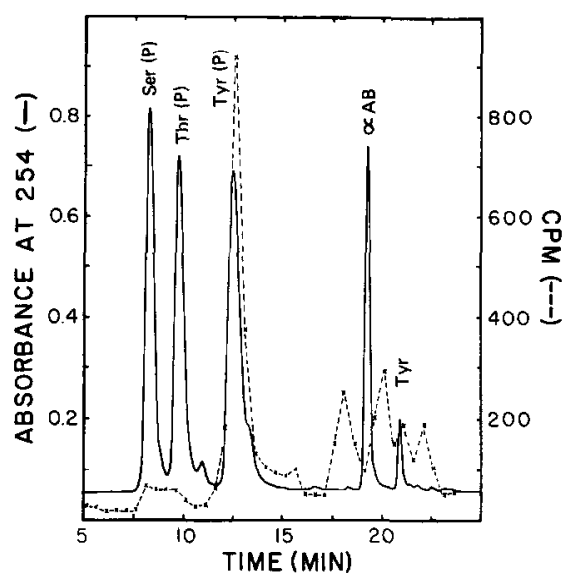

FIG. 2. HPLC elution profile of the absorbance (solid line) for a mixture of phenylthiocarbamyl derivatives of phosphoamino acids (62.5 nmol each) and of $\alpha$-aminobutyrate ( $\alpha \mathrm{AB}, 50 \mathrm{nmol}$ ). The mixture had been acid hydrolyzed and derivatized as described under Materials and Methods. The dashed line is the elution profile of cpm (for $0.5-\mathrm{ml}$ fractions, $x$ ) collected upon chromatography of the mixture of phosphoamino acids obtained from limited hydrolysis of the 95-kDa phosphorylated moiety as described under Materials and Methods. Ser(P), Thr(P), Tyr(P), $\alpha A B$, and Tyr are the elution positions of the phenylthiocarbamyl derivatives of a standard. Tyrosine was generated from phosphotyrosine during the acid hydrolysis $\left(6 \mathrm{~N} \mathrm{HCl}, 110^{\circ} \mathrm{C}\right.$ for $\left.1.5 \mathrm{~h}\right)$. The corresponding absorbance profile (not shown) for the sample from the $95-\mathrm{kDa}$ band had many peaks due to other amino acids and incompletely hydrolyzed tryptic peptides. The initial part of the chromatographs (not shown) contained a peak at the void volume.

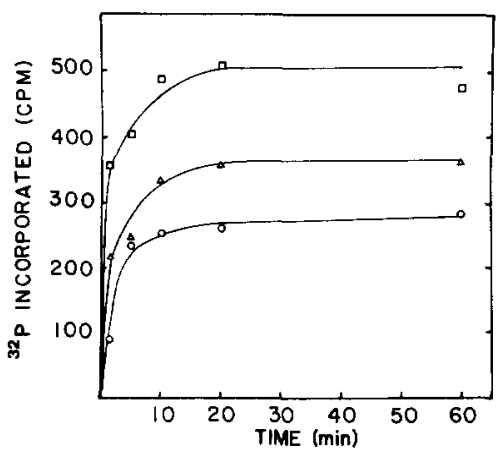

Fig. 3. Time course of insulin-dependent autophosphorylation of insulin receptor. WGA-purified receptor $(10 \mu \mathrm{g}$ in $100 \mu \mathrm{l})$ was phosphorylated at various concentrations of $\left[\gamma^{-32} \mathrm{P}\right] \mathrm{ATP}(\mathrm{O}, 25 \mu \mathrm{M} ; \Delta$, $50 \mu \mathrm{M} ; \square, 100 \mu \mathrm{M})$. Phosphorylation was terminated at the time indicated on the $x$ axis by heating the samples with DTT-containing Laemmli sample buffer for $3 \mathrm{~min}$. Proteins were separated by SDS-PAGE. The $95-\mathrm{kDa}$ subunit of insulin receptor was excised from the dried gel, and its radioactivity was measured. Shown is the insulin-dependent incorporation of phosphate into this subunit, after subtracting insulin-independent incorporation.

servations of insulin-mediated phosphorylation of the receptor with the WGApurified receptor are essentially the same as those recently reported by Shia and Pilch (14), using receptor from human placenta which had been partially purified by chromatography on hydroxylapatite and DEAE-trisacryl.

The time course of the insulin-dependent phosphorylation of the receptor is shown in Fig. 3 at several concentrations of ATP. The time dependencies illustrated in Fig. 3 indicate that, under the conditions used, phosphorylation was $50 \%$ complete within $2 \mathrm{~min}$. The dependence of the steady-state level of phosphorylated receptor on the ATP concentration is consistent with either the presence of a phosphatase, which catalyzes dephosphorylation of the receptor at a rate comparable to its rate of formation from ATP (at low ATP concentrations), or a low equilibrium constant for the formation of phosphorylated receptor.

To determine the relationship between phosphorylation and the binding of insulin, receptor was treated with the aminespecific crosslinking agent disuccinimidyl 

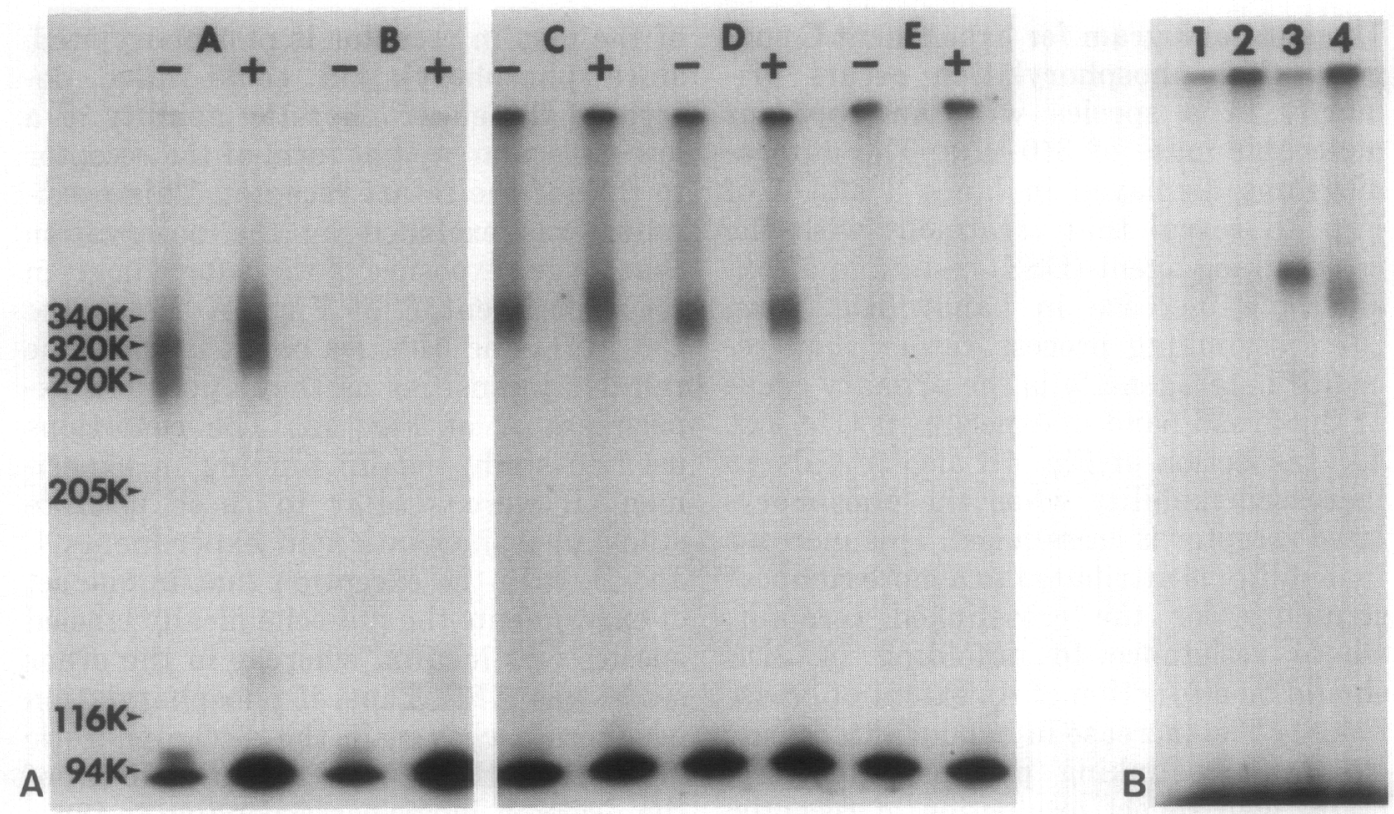

FIG. 4. Crosslinking of phosphorylated receptor. (A) WGA-purified receptor (20 $\mu \mathrm{g}$ in $200 \mu \mathrm{l})$ was incubated with $1.8 \mathrm{nM}^{125} \mathrm{I}-N^{\mathrm{eB} 29}$-biotinylinsulin $(\mathrm{A}, \mathrm{B}), 100 \mathrm{nM}$ insulin $(\mathrm{B}, \mathrm{D}), 100 \mathrm{nM} N^{\mathrm{B} 229_{-}}$ biotinylinsulin (C), and without insulin (E) for $15 \mathrm{~h}$ at $4^{\circ} \mathrm{C}$. Phosphorylation was carried out in $50 \mu \mathrm{M}$ ATP in the absence $(A, B)$ and presence $(C, D, E)$ of $\left[\gamma-{ }^{32} \mathrm{P}\right] \mathrm{ATP}$ at room temperature for 5 min. The samples were then crosslinked with $0.3 \mathrm{mM}$ DSS in ice for $45 \mathrm{~min}$. After denaturation with nonreducing sample buffers, and with $(+)$ and without $(-)$ treatment of succinylavidin, the samples were analyzed in SDS-PAGE, $4.5 \%$ gel (acrylamide:methylenebisacrylamide, 100:1). The molecular weight markers were myosin $(205 \mathrm{kDa}), \beta$-galactosidase $(116 \mathrm{kDa})$, and phosphorylase $b(94 \mathrm{kDa})$. Samples $A$ and $B$ and samples $C-E$ were run in the same gel, but autoradiographed for different time periods. (B) Phosphorylation was initiated after $1 \mathrm{~h}$ preincubation without $(1,2)$ and with $100 \mathrm{nM}$ insulin at room temperature. After phosphorylation for $5 \mathrm{~min}$, the samples were placed on ice for $45 \mathrm{~min}$ in the absence $(1,3)$ and presence $(2,4)$ of $0.3 \mathrm{mM}$ DSS. After denaturation with nonreducing sample buffer, the samples were analyzed in SDS-PAGE, 4.5\% gel.

suberate (DSS) in the presence of both ATP and insulin, or an insulin derivative, under the conditions used for phosphorylation wherein either the ATP was labeled in the $\gamma$ position with ${ }^{32} \mathrm{P}$ or the insulin was labeled with ${ }^{125}$ I. The autoradiogram in Fig. 4A (experiment $\mathrm{A}$ ) reveals the labeling of the 340-, 320-, and $290-\mathrm{kDa}$ species $^{5}$ usually obtained when insulin receptor was crosslinked in the presence of ${ }^{125}$ I-insulin, and subjected to SDS-PAGE

\footnotetext{
${ }^{5}$ The molecular masses reported in this work are only nominal values deduced from the mobilities of protein standards. The nominal values obtained for the molecular weights for the three forms of the insulin receptor correspond to previously reported values (see Ref. (24)).
}

without reduction. In experiments $\mathrm{A}-\mathrm{C}$ presented in Fig. 4A, $N^{\mathrm{EB} 29}$-biotinylinsulin was used rather than insulin. The same labeling pattern as that shown in the (-) lane of experiment $A$ for ${ }^{125} \mathrm{I}-N^{\mathrm{eB} 29}$-biotinylinsulin was obtained with ${ }^{125}$ I-insulin. The specificity of the affinity crosslinking reaction is illustrated in experiment $B$, wherein the presence of excess unlabeled insulin diminished the crosslinking of ${ }^{125}$ I$N^{\mathrm{B} 29}$-biotinylinsulin to the receptor.

As illustrated by the $(-)$ lane of experiment $\mathrm{C}$ of Fig. 4A, there was a pronounced change in the autoradiogram when the labeled moiety was changed so that the radiochemical label was in the ATP rather than in the biotinylinsulin. 
The autoradiogram for experiment $\mathrm{C}$ suggests that phosphorylation occurs primarily in a species with an apparent molecular mass of $340 \mathrm{kDa}$. The autoradiograms displayed in lanes 3 and 4 of Fig. 4B reveal that treatment with the crosslinking agent (DSS) results in a considerable increase in bandwidth. Thus, the crosslinking process rather than receptor heterogeneity is the primary cause of the broad band in experiment $\mathrm{C}$ of Fig. 4A. Inspection of Fig. $4 \mathrm{~B}$ also reveals an increased mobility when the phosphorylated receptor is crosslinked. This increase in mobility is attributed to a more compact structure for the crosslinked receptor, whose resistance to unfolding in SDS should be a function of its extent of crosslinking. The increase in band width caused by the crosslinking process, therefore, might well reflect production of receptor populations which differ with respect to their extent of crosslinking and electrophoretic mobility. The broadness of the band and the level of phosphorylation was unchanged when insulin was substituted for $N^{\mathrm{EB} 29}$-biotinylinsulin (compare the $(-)$ lanes of experiments $C$ and D in Fig. 4A). Additionally, a much reduced level of phosphorylation was seen in the absence of insulin (experiment $\mathrm{E}$ in Fig. $4 \mathrm{~A}$ and lanes 1 and 2 in Fig. 4B). A plausible explanation for the labeling of a single band with $\left[\gamma^{-32} \mathrm{P}\right] \mathrm{ATP}$ is that only the $340-\mathrm{kDa}$ insulin-binding form of the receptor undergoes autophosphorylation.

It is well established that insulin receptor as obtained from various sources is heterogeneous with respect to molecular weight. Massague et al. (24) attribute this heterogeneity to limited proteolysis of the $\beta$ subunit to a $\beta_{1}$ subunit, which gives rise to a mixture of $\alpha_{2} \beta \beta_{1}, \alpha_{2}\left(\beta_{1}\right)_{2}$, and intact $\alpha_{2} \beta_{2}$ tetramers. Shia and Pilch (14) have also observed that phosphorylation followed by SDS-PAGE under nonreducing conditions yields a single phosphorylated band which has the same electrophoretic mobility as the intact $\alpha_{2} \beta_{2}$ tetramer, and have concluded that only intact tetramer is autophosphorylated. This observation, however, does not unambiguously establish that the high-molecular-weight form of the insulin receptor is phosphorylated, since phosphorylation could have decreased the electrophoretic mobility of a low-molecular-weight form of the receptor to that of the intact receptor. This possibility was excluded by the observation that longer exposure of the autoradiogram for experiment $B$ of Fig. $4 A$ yields the 290-, 320-, and 340-kDa bands in the same relative intensities as they appear in experiment $\mathrm{A}$ of Fig. 4A. The conditions used to study insulin binding in experiment B were similar to those used to study phosphorylation in experiments $C$ and $D$, with the exception that in one set of experiments the radiochemically labeled species was insulin, whereas in the other set it was ATP. Thus, if phosphorylation produced a change in the electrophoretic mobility of the 320 - or $290-\mathrm{kDa}$ forms of the receptor, bands corresponding to those forms should have been absent when the insulin contained the label.

The fact that only a minor population of the receptor appears to be phosphorylated makes it important to verify that insulin receptor was phosphorylated rather than a closely associated contaminant. Although the observation that antibodies to the insulin receptor precipitate the phosphorylated $340-\mathrm{kDa}$ protein provides strong evidence that insulin receptor is phosphorylated, the possibility has not been excluded that the phosphorylated protein represents a $340-\mathrm{kDa}$ contaminant which is closely associated with the receptor. This possibility was excluded by demonstrating that the molecules which were phosphorylated were also competent to bind insulin. To do this a double-probe labeling protocol was used wherein the first probe was a ${ }^{32} \mathrm{P}$-labeled phosphoryl group and the second probe was $N^{\mathrm{B} 29}$ biotinylinsulin. ${ }^{6}$ If insulin receptor molecules retained their competence to bind insulin after phosphorylation, they should

\footnotetext{
${ }^{6}$ It is important to note that studies of the capacity of a phosphorylated receptor preparation to bind insulin will not reveal the competence of the phosphorylated protein to bind insulin, since this protein represents a minor population of the insulin binding proteins in the preparation.
} 
become covalently bound to both ${ }^{32} \mathrm{P}$ and $N^{\mathrm{EB} 29}$-biotinylinsulin upon affinity crosslinking. Such ${ }^{32}$ P-labeled molecules should exhibit an increased molecular weight and decreased electrophoretic mobility upon treatment with succinylavidin prior to electrophoresis. The ability of succinylavidin to decrease the electrophoretic mobility during SDS-PAGE of receptor linked to $N^{\mathrm{e} 29}$-biotinylinsulin has been previously reported $(22,23)$, and is illustrated in experiment $\mathrm{A}$ of Fig. $4 \mathrm{~A}$ (compare $(-)$ and $(+)$ lanes which indicate treatment without $(-)$ and with $(+)$ succinylavidin). The observation that treatment with succinylavidin decreases the electrophoretic mobility of the $340-\mathrm{kDa}$ phosphorylated species (compare $(-)$ and (+) lanes of experiment C, Fig. 4A) proves that the phosphorylated receptor is competent to bind insulin. The control, experiment $D$, shows that the succinylavidin treatment has no effect on the electrophoretic mobility of insulin receptor crosslinked in the presence of native insulin rather than biotinylinsulin. Examination of the autoradiogram in experiment $\mathrm{C}$ with a scanning densitometer indicated that, prior to treatment with succinylavidin, there appears to be one broad peak which could be represented by a single Gaussian function but that treatment with succinylavidin resulted in the appearance of two overlapping peaks. The fraction of each component was determined with the aid of a computer program which fit the dependence of density on distance to the sum of two Gaussians. One of the components was assumed to be crosslinked receptor which did not become covalently linked to $N^{\mathrm{E} 29}$-biotinylinsulin and which therefore did not interact with the succinylavidin. The values for the standard deviation and the peak position for the component which did not interact with succinylavidin was assumed to be the same as those observed for the single peak obtained in the absence of succinylavidin. The fraction of each component indicated that only about $60 \%$ of the phosphorylated receptor was crosslinked to the biotinylinsulin probe, when the concentration of this probe was $100 \mathrm{nM}$. Crosslinking effi- ciencies of $42-48 \%$ were observed at concentrations of 5,10 , and $40 \mathrm{nM} N^{\mathrm{B} 29}$ biotinylinsulin. These crosslinking efficiencies are within experimental error of the average value of $52 \%$ we obtained for the crosslinking efficiency for this probe when it binds to receptor in the absence of ATP (23). The correspondence between these efficiencies indicates that essentially all of the phosphorylated receptor molecules are bound to at least one molecule of insulin probe at insulin concentrations $\geqslant 5 \mathrm{nM}$. It is important to note, however, that we have not ruled out the possibility that phosphorylation of the receptor quantitatively alters its affinity for insulin. Quantification of the alteration (if any) in the affinity of the receptor for insulin caused by phosphorylation will probably require studies with pure, intact receptor. New purification protocols must be developed, however, to obtain pure intact receptor kinase, since the published affinity chromatography procedures (e.g. (25)) yield preparations wherein the active intact receptor kinase is grossly contaminated by enzymatically inactive, low-molecular-weight forms of the receptor.

Receptor crosslinked in the presence of $100 \mathrm{nM}$ insulin and $50 \mu \mathrm{M}\left[\gamma^{32} \mathrm{P}\right] \mathrm{ATP}$ was reduced and subjected to SDS-PAGE to determine the accessibility of the $\alpha-\alpha, \beta-$ $\beta$, and $\alpha-\beta$ subunit interfaces to the crosslinking agent DSS. The autoradiograms in Fig. 5 indicate that reduction of the major ${ }^{32} \mathrm{P}$-containing band at $340 \mathrm{kDa}$ (lane 1) results in the formation of three bands with electrophoretic mobilities corresponding to 95,190 , and $380 \mathrm{kDa}$. The most plausible explanation of this observation is that the $95-\mathrm{kDa}$ band represents phosphorylated $\beta$ subunits which were not crosslinked to other subunits, and that the other ${ }^{32} \mathrm{P}$-containing bands reflect crosslinking of the $\beta$ chain to other chains (see below).

Figure 6 depicts the effect of reduction (with DTT) of receptor which was crosslinked in the presence of ${ }^{125}$ I-insulin. Lane 1 of Fig. $6 \mathrm{~A}$ shows the three major insulin binding forms at 290,320 , and $340 \mathrm{kDa}$ obtained upon crosslinking the receptor without subsequent treatment with re- 


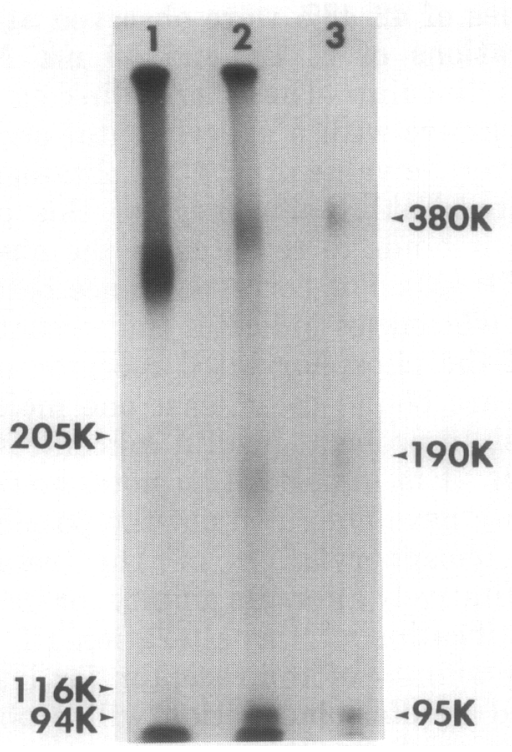

FIG. 5. Subunit composition of crosslinked phosphorylated receptor. After $1 \mathrm{~h}$ preincubation with $100 \mathrm{nM}$ insulin, the receptor $(10 \mu \mathrm{g}$ in $100 \mu \mathrm{l})$ was phosphorylated with $50 \mu \mathrm{M}\left[\gamma^{\mathrm{a}}{ }^{2} \mathrm{P}\right] \mathrm{ATP}$ for $5 \mathrm{~min}$, crosslinked with $0.3 \mathrm{mM}$ DSS, and denatured by heating the sample for $3 \mathrm{~min}$ with sample buffer without (1) and with (2) $25 \mathrm{mM}$ DTT. Sample (3) was the gel band of the $340-\mathrm{kDa}$ phosphorylated receptor which was excised from a previous gel and treated with sample buffer containing $25 \mathrm{~mm}$ DTT. With molecular weight markers (myosin, $\beta$-galactosidase, and phosphorylase $b$ ) for calibration, the three major bands in (3) were estimated to be, from the top, 380, 190, and $95 \mathrm{kDa}$.

ducing agent. Lane 2 shows the ability of unlabeled insulin to diminish this labeling pattern, and demonstrates the specificity of the affinity crosslinking procedure. Lanes 3, 4, and 5 demonstrate the effect of treatment with increasing concentrations of DTT on the electrophoretic pattern of the radioactive bands. Interestingly, reduction gives rise primarily to two bands with apparent $M_{\mathrm{r}}$ 's of 125 and $240 \mathrm{kDa}$. Figure 6B, wherein bands corresponding to 290,320 , and $340 \mathrm{kDa}$ were excised from the gel and separately reduced, shows that each species gives rise to the 125- and $240-\mathrm{kDa}$ species. Close examination of the autoradiograms in lanes 6,7 , and 8 reveals that reduction of each of the bands in lanes 3,4 , and 5 gives rise to small amounts of species which migrate as if they had molecular weights about $40 \mathrm{kDa}$ higher than the parent bands. These bands of increased molecular weight, and the $380-\mathrm{kDa}$ band produced upon reduction of the $340-\mathrm{kDa}$ crosslinked receptor labeled with ${ }^{32} \mathbf{P}$ (Fig. 5), are attributed to receptor which was crosslinked to such an extent that reduction of interchain disulfide bonds did not result in dissociation of the subunits comprising the receptor. The increase in apparent $M_{\mathrm{r}}$ is attributed to partial unfolding of crosslinked receptor upon reduction of the disulfide bands with DTT.

The $125-\mathrm{kDa}$ band is attributed to $\alpha$ chains which were not crosslinked to other polypeptide chains. The $240-\mathrm{kDa}$ band cannot be attributed to a crosslinked $\alpha \beta$ dimer, since a band having the same apparent molecular weight should have been observed when crosslinked receptor labeled with $\left[{ }^{32} \mathrm{P}\right]$ phosphate was reduced. Thus it is reasonable to attribute the 240$\mathrm{kDa}$ band to a crosslinked $\alpha$ dimer, and to attribute the $190-\mathrm{kDa}$ band observed with receptor labeled with $\left[{ }^{32} \mathrm{P}\right]$ phosphate to a crosslinked $\beta$ dimer. Our observation of a small amount of receptor tetramer that cannot be dissociated with even 25 mM DTT in the presence of SDS strongly suggests that the crosslinking agent DSS can crosslink the $\alpha \beta$ interface. Crosslinking at the $\alpha \beta$ interface, however, is probably markedly slower than crosslinking at either the $\alpha \alpha$ or $\beta \beta$ subunit interface, as evidenced by the failure to accumulate detectable levels of crosslinked $\alpha \beta$ dimer. The reactivity of the $\alpha \alpha$ and $\beta \beta$ subunit interfaces of the receptor suggests that a substantial segment of these subunit interfaces contain hydrophilic amino groups

\footnotetext{
${ }^{7}$ Crosslinks present in the tetramer may cause it to resist complete unfolding. Thus, the discrepancy between the apparent molecular mass of $380 \mathrm{kDa}$ observed for the intact tetramer and the value of $440 \mathrm{kDa}$ expected from the mass of two $\alpha$ and two $\beta$ chains may reflect an anomalously high electrophoretic mobility of a partially unfolded protein. Experimental error and the uncertainty associated with estimates of the mass of glycoproteins from their electrophoretic mobilities could also contribute to the discrepaney.
} 

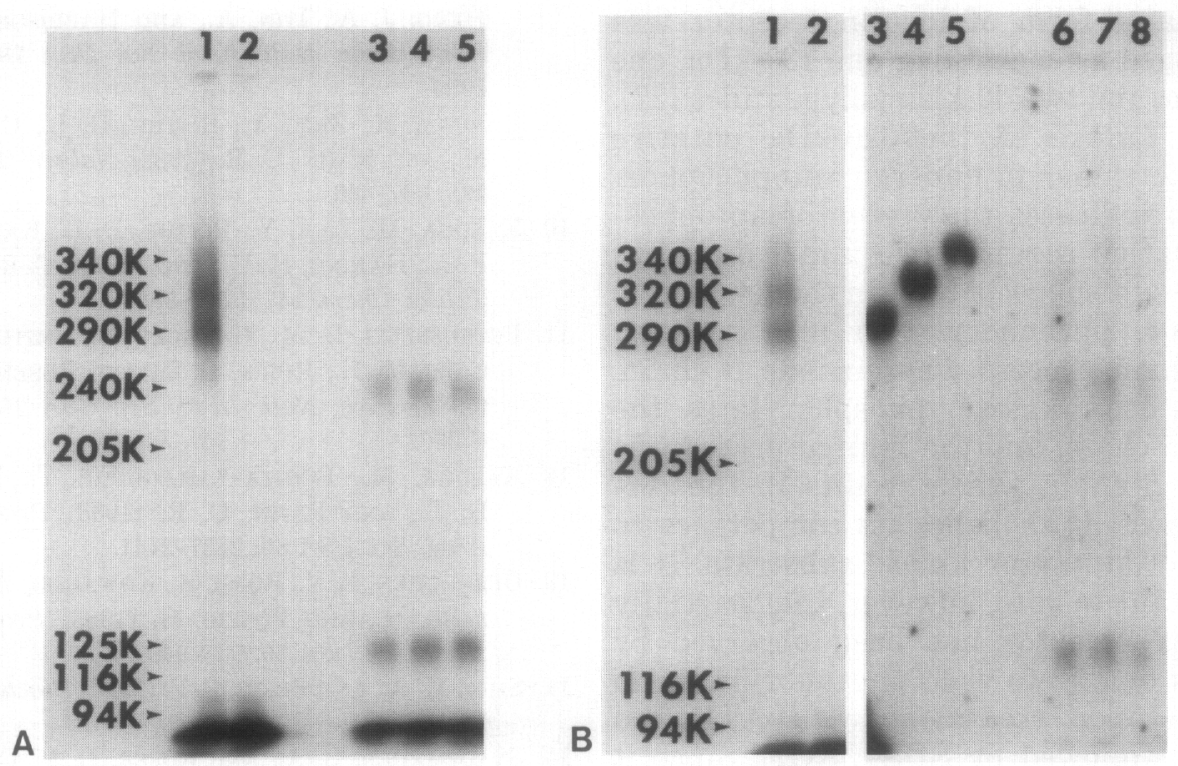

FIG. 6. Subunit composition of insulin receptor crosslinked with ${ }^{125} \mathrm{I}$-insulin. (A) Insulin receptor $(10 \mu \mathrm{g}$ in $200 \mu \mathrm{l})$ was incubated with $6 \mathrm{nM}{ }^{125} \mathrm{I}$-insulin in $25 \mathrm{mM}$ Hepes, $\mathrm{pH} 7.6,0.1 \mathrm{M} \mathrm{NaCl}, 0.1 \%$ BSA, 0.05\% Triton, without (1) and with (2) $0.5 \mu \mathrm{M}$ insulin, at $4^{\circ} \mathrm{C}$ for $16 \mathrm{~h}$. The samples were crosslinked with $0.3 \mathrm{mM}$ DSS at $0^{\circ} \mathrm{C}$ for $45 \mathrm{~min}$, and were denatured by heating in nonreducing sample buffer. Sample (1) was also treated with increasing concentrations of DTT: 25 (3), 50 (4), and $75 \mathrm{mM}$ (5). The samples were run in a $4.5 \%$ gel. These high concentrations of DTT were used to exclude the possibility that the band which migrated in the range of $240 \mathrm{kDa}$, after treatment with lower concentrations of DTT, was due to incompletely reduced material. (B) Sample (1) and (2) were identical to (A), but in a separate gel. Samples $(3,6),(4,7)$, and $(5,8)$ were the excised gel bands from (A) with $M_{r}$ 's of 290,320 , and $340 \mathrm{kDa}$, respectively. Samples 6-8 were treated with 25 mM DTT, whereas 3-5 were not. High-molecular-weight bands, (barely detectable in this exposure) in 6,7 , and 8 were estimated to be 320,340 , and $380 \mathrm{kDa}$, respectively. Samples 1-8 were run in the same gel, but samples 3-8 were autoradiographed longer in order to show the radioactive bands in 6-8. The marked reduction in the intensity of the bands upon reduction is consistent with the view that the insulin is primarily labeled with ${ }^{125} \mathrm{I}$ in the $\mathrm{A}$ chain whereas the $B$ chain is primarily crosslinked to the receptor. Although the autoradiograms depicted in (A) were obtained in presence of $6 \mathrm{nM}{ }^{125} \mathrm{I}$-insulin and no ATP, the bands attributed to $\alpha$ monomer $(125 \mathrm{kDa})$ and $\alpha$ dimer $(240 \mathrm{kDa})$ were also obtained when the insulin receptor was crosslinked under phosphorylation conditions (in the presence of ATP and $\mathrm{Mn}^{+2}$ and higher concentrations of ${ }^{125}$ I-insulin) similar to those used for the experiments described in Fig. 5. Under these conditions as well as in the absence of ATP, no band which could be attributed to $\alpha \beta$ dimer was observed. In Fig. 6 a low concentration of high-specific-activity ${ }^{125} \mathrm{I}$-insulin was used to maximize receptor labeling so that the subunit composition of each of the insulin binding forms could be examined individually.

which are accessible to the crosslinking agent.

Our observation that reduction of affinity crosslinked receptor yields $\alpha$ dimer and $\beta$ dimer indicates that the intact receptor must contain two $\alpha$ and two $\beta$ chains, and provides strong support for the symmetrical, tetrameric, $\alpha_{2} \beta_{2}$ model which has been proposed for the structure of insulin receptors $(1,4,26)$. The finding that reduction of each of the 340-, 320-, and $290-\mathrm{kDa}$ forms of the crosslinked receptor yields a mixture of $\alpha$ dimer and $\alpha$ monomer is consistent with the conclusion that the heterogeneity of the receptor is due primarily to limited proteolysis of the $\beta$ chain (24). This finding also rules out (at least for insulin receptor from human placenta) an alternative model proposed for the structure of the receptor, wherein 
the major form of insulin receptor was envisaged as containing one $130-\mathrm{kDa}$, one 90-kDa, and two 40-kDa polypeptides (27).

The failure of the $320-\mathrm{kDa}$ putative $\alpha_{2} \beta \beta_{1}$ tetramer to undergo autophosphorylation indicates that receptor autophosphorylation requires two intact $\beta$ chains. This result suggests that, in the tetrameric receptor, phosphorylation might be an interchain process wherein one $\beta$ chain, acting as a kinase, phosphorylates the other $\beta$ chain, and the limited proteolysis of the $\beta$ chain which results in the formation of $\beta_{1}$ abolishes its competence to act as a kinase or kinase substrate. It is important to note, however, that partially reduced receptor has been observed by Shia et al. (28) to yield phosphorylated $\alpha \beta$ dimers upon treatment with ATP and insulin followed by SDS-PAGE. Since it is not clear whether the $\alpha \beta$ dimers dissociated from the reduced tetrameric receptor prior to phosphorylation and prior to addition of SDS, it is difficult to conclude from this observation whether isolated $\alpha \beta$ dimers are competent to undergo autophosphorylation. The competence of isolated $\alpha \beta$ dimers to undergo unimolecular autophosphorylation would, of course, exclude the possibility that autophosphorylation requires interaction between the two $\beta$ chains.

\section{REFERENCES}

1. JaCOBS, S., AND Cuatrecasas, P. (1983) Annu. Rev. Pharmacol Toxicol 23, 461-479.

2. Flier, J. S. (1983) Annu. Rev. Med 34, 145-160.

3. PILCH, P. F., AND CzECH, M. P. (1980) J. Biol. Chem 255, 1722-1731.

4. Massague, J., AND Czech, M. P. (1982) J. Biol Chem. 257, 6729-6738.

5. YIP, C. C., Yeung, C. W. T., AND Moule, M. L. (1980) Biochemistry 19, 70-76.

6. Hedo, J. A., Kahn, C. R., HaYashi, M., Yamada, K. M., AND KaSUGA, M. (1983) J. Biol Chem. 258, 10020-10026.

7. Deutsch, P. J., WaN, C. F., Rosen, O. M., AND Rubin, C. S. (1983) Proc. Nath Acad. Sci. USA 80, 133-136.

8. Obberghen, E. V., Kasuga, M., CaM, A. L.,
Hedo, J. A., Itin, A., and Harrison, L. C. (1981) Proc. Nath Acad. Sci USA 78, 10521056.

9. Kasuga, M., Zick, Y., Blithe, D. L., Crettaz, M., AND KAHN, C. R. (1982) Nature (Londom) 298, 667-669.

10. KASUGA, M., ZICK, Y., Blithe, D. L., KARISSON, F. A., HÄRING, H. U., AND KAHN, C. R. (1982) J. Biol. Chem. 257, 9891-9894.

11. Petruzzelli, L. M., Ganguly, S., Smith, C. J., Cobe, M. H., Rubin, C. S., aNd Rosen, O. M. (1982) Proc. Natl Acad. Sci. USA 79, 67926796.

12. Kasuga, M., Fugita-Yamaguchi, Y., Blithe, D. L., AND KAHN, C. R. (1983) Proc. Nath. Acad Sci. USA 80, 2137-2141.

13. Obberghen, E. V., Rossi, B., Kowalski, A., GaZzano, H., ANd Ponzio, G. (1983) Proc. Natl. Acad. Sci. USA 80, 945-949.

14. ShIA, M. A., AND PILCH, P. F. (1983) Biochemistry 22, 717-721.

15. Stadtmauer, L. A., and Rosen, O. M. (1983) $J$. Biol Chem. 258, 6682-6685.

16. Rosen, O. M., Herrera, R., Olowe, Y., Petruzzelli, L. M., AND CoBB, M. H. (1983) Proc. Nath Acad. Sci. USA 80, 3237-3240.

17. Bishop, J. M. (1983) Annu. Rev. Biochem. 52, 301-354.

18. Carter-Su, C., and Pratt, W. B. (1984) in The Receptors (Conn, P. M., ed.) Academic Press, New York, in press.

19. LAEMMLI, U. K. (1970) Nature (London) 227, 680685.

20. LASKeY, R. A., AND MILLS, A. D. (1975) Eur. J. Biochem. 56, 335-341.

21. Koop, D. R., Morgan, E. T., Tarr, G. E., AND CoON, M. J. (1982) J. Biol. Chem. 257, 84728480.

22. Pang, D. T., AND Shafer, J. A. (1983) J. Biol Chem. 258, 2514-2518.

23. Pang, D. T., AND Shafer, J. A. (1984) J. Biol Chem. 259, 8589-8596.

24. Massague, J., PILCh, P. F., aNd Czech, M. P. (1980) Proc. Natl. Acad. Sci. USA 77, 71377141.

25. Fujita-Yamaguchi, Y., Choi, S., Sakamoto, Y., AND Itakura, K. (1983) J. Biol Chem. 258, 5045-5049.

26. Pollet, R. J., Kempner, E. S., St'tandaert, M. L., AND HAASE, B. A. (1982) J. Biol. Chem. 257, 894-898.

27. YIP, C. C., AND Moule, M. L. (1983) Fed. Proc. 42, 2842-2845.

28. ShiA, M. A., Rubin, J. B., AND PILCH, P. F. (1983) J. Biol Chem. 258, 14450-14455. 